\title{
Puna-apilasäilörehun vaikutus lypsylehmien ravintoaineiden saantiin
}

\author{
Aila Vanhatalo, ${ }^{1,2)}$, Kaisa Kuoppala ${ }^{1)}$, Seppo Ahvenjärvi ${ }^{1)}$ ja Marketta Rinne ${ }^{1)}$ \\ 1) MTT Eläinravitsemus, 31600 Jokioinen, etunimi.sukunimi@mtt.fi \\ ${ }^{2)}$ Nykyinen osoite: Kotieläintieteen laitos, PL 28, 00014 Helsingin yliopisto, \\ aila.vanhatalo@helsinki.fi
}

\section{Tiivistelmä}

Typensidontakykynsä vuoksi puna-apila on tärkeä säilörehun raaka-aine erityisesti luomumaidontuotannossa. Puna-apilapitoisen säilörehun tuotantovaikutuksesta heinäsäilörehuun verrattuna on olemassa aikaisempaa tutkimustietoa. Puna-apilan vaikutusmekanismeja selvittäviä fysiologisia tutkimuksia on kuitenkin tehty verrattain vähän. Tässä tutkimuksessa selvitettiin kasvilajin (heinäkasvi vs. puna-apila) ja kasvuasteen (aikainen vs. myöhäinen korjuu) vaikutusta lypsylehmien tuotosvasteisiin, pötsikäymiseen ja ravintoaineiden virtaukseen pötsistä sekä veriparametreihin.

Vaikka käytännön ruokinnassa käytetään yleensä puna-apilan ja heinäkasvin seoksia, tässä kokeessa säilörehut tehtiin puhtaista apilakasvustoista, jotta voitaisiin selvittää juuri puna-apilan vaikutuksia ruokinnassa. Säilörehut tehtiin ensimmäisestä sadosta kahdessa eri kehitysvaiheessa olevasta timotei-nurminata- ja puna-apilakasvustosta. Timotei-nurminatasäilörehut korjattiin 17.6. (aikainen kasvuaste, Ha) ja 26.6. (myöhäinen kasvuaste, Hm) ja puna-apilasäilörehut 2.7. (aikainen, Aa) ja 16.7. (myöhäinen, Am). Säilörehuja syötettiin pötsifistelöidyille lypsylehmille 5 x 5 latinalaisen neliön mukaisessa fysiologisessa kokeessa. Viidentenä ruokintana oli Hm:n ja Aa:n 1:1 seos. Väkirehua kaikki lehmät saivat 9 kg päivässä. Koesäilörehujen pässeillä mitatut sulavan orgaanisen aineen pitoisuudet olivat 714 (Ha), 673 (Hm), 678 (Aa), ja 610 (Am) g/kg kuiva-ainetta.

Heinäkasvirehuista poiketen lehmät söivät puhtaasta puna-apilasta tehtyä aikaisin korjattua säilörehua vähemmän kuin myöhemmin korjattua apilarehua. Eniten lehmät söivät Hm- ja Aa-rehujen seosta. Syöntieroista huolimatta lehmien maitotuotoksissa ei ollut merkitseviä eroja. Apilaruokinnat pienensivät kuitenkin selvästi maidon rasva- ja valkuaispitoisuuksia, ja nostivat maidon ureapitoisuuksia. Rasvapitoisuuden pieneneminen apilaruokinnoilla oli yhteydessä heinäkasviruokintoja pienempään voihapon osuuteen pötsissä muodostuvista haihtuvista rasvahapoista. Pötsistä virtaavan ei-ammoniakki- ja aminotypen määrä oli suurempi apila- kuin heinäkasviruokinnoilla johtuen lähinnä rehuperäisen typen suuremmasta virtauksesta. Myös välttämättömien aminohappojen ja urean pitoisuudet valtimoveren plasmassa olivat suurempia apilakuin heinäkasviruokinnoilla.

Kokeen tulokset viittaavat siihen, että nurmen kasvuasteen vaikutus säilörehun syöntiin ja ravintoaineiden saantiin apilalla ja heinäkasveilla ei ole samanlainen. Apilan kasvuasteen vaikutuksista lehmien tuotosvasteisiin tarvitaan lisätutkimuksia.

Puna-apilan käyttö ruokinnassa lisää lypsylehmien aminohappojen saantia heinäkasviruokintoihin verrattuna. Puhdasta puna-apilaa käytettäessä rehuannoksen raakavalkuaispitoisuus voi kuitenkin nousta tarpeettoman suureksi, jolloin rehuvalkuaisen hyväksikäyttö väistämättä huononee

Asiasanat: lypsylehmä, säilörehu, puna-apila, mikrobivalkuainen, aminohappo 


\section{Johdanto}

Typensidontakykynsä vuoksi puna-apila on tärkeä säilörehun raaka-aine erityisesti luomumaidontuotannossa. Käytännössä puna-apilaa viljellään useimmiten seoksena heinäkasvien kanssa, ja sen sisällyttäminen ruokintaan on yleensä lisännyt sekä säilörehun syöntiä että maitotuotosta puhtaaseen heinäkasvisäilörehuun verrattuna (Thomas ym. 1985, Heikkilä ym. 1992, Tuori ja Syrjälä-Qvist 2001, Dewhurst ym. 2003). Joissakin kokeissa puna-apila on pienentänyt maidon rasva- (Thomas ym. 1985, Heikkilä ym. 1992, Tuori ym. 2002) tai valkuaispitoisuuksia (Bertilsson ja Murphy 2003).

Puna-apilan tuotantovaikutuksia selittäviä fysiologisia tutkimuksia on tehty verrattain vähän. Aikaisemmin tehdyn kotimaisen fysiologisen tutkimuksen mukaan sekä mikrobivalkuaisen tuotanto pötsissä että rehuperäisen valkuaisen virtaus pötsistä oli runsaampaa puna-apilapitoista (40\%) kuin puhdasta nurminata-timoteisäilörehua syötettäessä (Vanhatalo ym. 1995). Myös Dewhurst'in ym. (2003) kokeessa ohutsuoleen virtasi puna-apilaa sisältävillä ruokinnoilla enemmän eiammoniakkityppeä (NAN) kuin raiheinäsäilörehuruokinnalla. Lähes kaikissa aikaisemmissa tutkimuksissa puna-apilan ja heinäkasvin ruokinnallista arvoa on verrattu vain yhdellä kasvuasteella.

Tämän tutkimuksen tarkoituksena oli selvittää puna-apilasäilörehun kasvuasteen vaikutusta lypsylehmien pötsikäymiseen, ravintoaineiden virtaukseen pötsistä ja tuotosvasteisiin vastaavilla kasvuasteilla korjattuihin timotei-nurminatasäilörehuihin verrattuna. Solunseinäkuidun sulatusta ja virtauskinetiikkaa koskevat tulokset on esitetty rinnakkaispaperissa (Kuoppala ym. 2006). Tutkimus tehtiin MMM:n rahoittaman Luomututkimusohjelman puitteissa.

\section{Aineisto ja menetelmät}

Koesäilörehut tehtiin Jokioisissa kesällä 2003 ensimmäisen vuoden puna-apilasta (lajike Jokioinen) ja timotei-nurminadasta (lajikkeet Tammisto II ja Antti, 54 ja 46 \% siemenseoksessa). Heinäkasvinurmi oli lannoitettu Suomen salpietarilla, $91 \mathrm{~kg} \mathrm{~N} / \mathrm{ha}$, mutta puna-apilanurmea ei lannoitettu lainkaan. Kummankin kasvilajin säilörehut korjattiin nurmen ensikasvusta joko aikaisin tai myöhään tarkoituksena korjata kasvilajit kasvuasteittain samassa sulavuudessa. Tällöin timoteinurminatasäilörehut korjattiin 17.6. (aikainen kasvuaste, Ha) ja 26.6. (myöhäinen kasvuaste, Hm) ja puna-apilasäilörehut 2.7. (aikainen, Aa) ja 16.7. (myöhäinen, Am). Nurmet niitettiin niittomurskaimella ja heinäkasvinurmi esikuivatettiin karholla $\mathrm{n} .3 \mathrm{~h}$ ja puna-apila $\mathrm{n} .7 \mathrm{~h}$, jonka jälkeen rehu korjattiin tarkkuussilppurilla. Rehujen tavoitekuiva-ainepitoisuus oli n. $25 \%$ ja ne säilöttiin laakasiiloihin tai aumoihin käyttäen AIV2 Plus -säilöntäainetta (timotei-nurminata 5 l/t ja apila 6 l/t).

Fysiologinen koe tehtiin viidellä pötsifistelöidyllä Ay-lehmällä MTT:n koe-eläintallilla Jokioisissa. Koe toteutettiin $5 \times 5$ latinalaisena neliönä, johon koekäsittelyt oli järjestetty $2 \times 2$ faktoriaalisesti siten, että tutkittavina tekijöinä olivat kasvilaji (apila vs. heinäkasvi) ja kasvuaste (aikainen vs. myöhäinen). Lisäksi viidentenä koekäsittelynä oli kasvilajien seos (Hm ja Aa, 1:1 kuivaaineena). Säilörehua annettiin lehmille vapaasti ja väkirehua 9 kg/pv. Koejakson (3 viikkoa) viimeisen viikon aikana säilörehua annettiin 95 \% edellisen viikon vapaasta syönnistä syöntimäärien vaihtelun pienentämiseksi. Säilörehu ja väkirehu jaettiin lehmille neljä kertaa päivässä klo 6, 9, 18 sekä 20. Väkirehuseos sisälsi ohraa 40,5 \%, kauraa $40 \%$, rypsipuristetta $16 \%$ ja kivennäistä 3,5 \%. Väkirehun koostumus ja määrä olivat luomusäännösten mukaisia. Koesäilörehujen valmistus ja väkirehun koostaminen on selostettu tarkemmin rinnakkaispaperissa (Kuoppala ym. 2005).

Lehmien rehunkulutus ja maidontuotanto mitattiin päivittäin. Rehuista otettiin jokaista koejaksoa vastaavat näytteet. Maidon koostumuksen määrittämiseksi otettiin maitonäytteet neljänä peräkkäisenä lypsykertana jokaisen jakson aikana. Pötsikäymisen mittaamista varten eläimiltä otettiin pötsinestenäytteet yhden päivän aikana 1,5 h:n välein klo 6-18. Ravintoaineiden virtaus pötsistä määritettiin kolmoismerkkiaine- ja satakertanäytteenottomenetelmää käyttäen (Ahvenjärvi ym. 2000). Ruokasulan nesteosan merkkiaineena käytettiin Cr-EDTA:a, pienten partikkeleiden Yb-asetaattia ja suurten partikkeleiden merkkiaineena sulamatonta kuitua. Mikrobitypen virtauksen merkkiaineena käytettiin ${ }^{15} \mathrm{~N}$-rikastettua ammoniumsulfaattia. Ruokasulanäytteet kerättiin neljän päivän aikana siten, että jokaista puolen vuorokauden (12 h) tuntia kohden saatiin yksi näyte. Dieetin ravintoaineiden kokonaissulavuuden määrittämiseksi järjestettiin neljän vuorokauden pituinen sonnan kokonaiskeruu. Lisäksi jokaisen jakson viimeisenä päivänä lehmien häntä- ja maitosuonista otettiin verinäytteet klo 6 , 9 ja 12 plasman aminohappojen ja energiaparametrien määrittämistä varten. Sulamaton kuitu määritettiin inkuboimalla näytteitä 12 vrk nailonpusseissa lypsylehmien pötsissä. Säilörehujen orgaanisen aineen sulavuus määritettiin pässeillä sonnan kokonaiskeruumenetelmää käyttäen. 
Rehu- ja muut näytteet analysoitiin MTT:n Eläinravitsemuksen laboratoriossa. Käytetyt koetekniikat kemiallisine analyyseineen on selostettu yksityiskohtaisesti muualla (Korhonen ym. 2002b). Tulosten tilastollinen käsittely tehtiin varianssianalyysillä SAS GLM tai MIXED -ohjelmistoja käyttäen. Ruokinnan vaikutus jaettiin ortogonaalisin kontrastein kasvilajin (puna-apila vs. heinäkasvi) ja kasvuasteen (aikainen vs. myöhäinen) vaikutuksiin, niiden yhdysvaikutukseen sekä seoksen ja sen komponenttien vertailuun.

\section{Tulokset ja tulosten tarkastelu}

Timotei-nurminatasäilörehujen kuiva-ainepitoisuus oli suurempi kuin apilarehujen, mutta kaikki säilörehut olivat siilossa rajoittuneesti käyneitä ja säilönnälliseltä laadultaan moitteettomia (taulukko 1). Valkuaisen hajoamista siilossa kuvaavien ammoniakki-N:n ja liukoisen typen osuudet kokonaistypestä olivat apilarehuissa pienempiä kuin heinäkasvirehuissa heijastaen puna-apilan sisältämän polyfenolioksidaasin valkuaisen hajoamista ehkäisevää vaikutusta (Jones 1995). Apilarehujen raakavalkuaispitoisuudet olivat tyypillisesti suurempia ja NDF-kuitupitoisuudet pienempiä kuin heinäkasvirehuissa. Tavoitteen mukaisesti aikaisin korjatut heinäkasvi- ja apilarehut saatiin korjattua lähes samassa orgaanisen aineen sulavuudessa (777 vs. 758 g/kg). Myöhään korjattujen heinäkasvi- ja apilarehujen sulavuuksissa oli kuitenkin eroa (729 vs. 672 g/kg).

Lehmät söivät apilarehuja keskimäärin hiukan vähemmän kuin heinäkasvirehuja (taulukko 2). Apilan ja heinäkasvin seosta lehmät söivät kuitenkin merkitsevästi $(\mathrm{P}<0.01)$ enemmän kuin kumpaakaan seokseen kuuluvaa rehua yksinään. Sama ilmiö todettiin Tuorin ym. (2002) kokeessa, jossa nurminatasäilörehua korvattiin puhtaalla puna-apilasäilörehulla. Kasvuasteen edetessä heinäkasvirehun syönti odotetusti väheni (Rinne 2000), mutta apilarehun syönti sen sijaan lisääntyi $(\mathrm{P}<0.10)$, mikä oli yllättävää, sillä molempien kasvilajien kohdalla myöhään korjattujen säilörehujen orgaanisen aineen ja NDF:n pötsi- ja kokonaissulavuudet olivat huonompia kuin aikaisin korjattujen rehujen. Ruokinnan orgaanisen aineen ja NDF:n kokonaissulavuuksissa ei ollut suuria kasvilajien välisiä eroja, joskin pötsisulatuksen osuus NDF:n kokonaissulatuksesta oli apilaruokinnoilla pienempi kuin heinäkasviruokinnoilla.

Taulukko 1. Rehujen kemiallinen koostumus ja säilörehujen käymislaatu.

\begin{tabular}{|c|c|c|c|c|c|}
\hline & Ha & $\mathrm{Hm}$ & Aa & Am & Väkirehu \\
\hline Korjuupäivä v. 2003 & 17.6. & 26.6. & 2.7 . & 16.7. & \\
\hline Kuiva-aine (ka), g/kg & 249 & 257 & 214 & 212 & 890 \\
\hline $\mathrm{pH}$ & 4,04 & 3,97 & 4,15 & 4,10 & \\
\hline \multicolumn{6}{|l|}{ Kuiva-aineessa, g/kg } \\
\hline Tuhka & 86 & 75 & 102 & 93 & 54 \\
\hline Raakavalkuainen & 134 & 111 & 212 & 181 & 167 \\
\hline NDF & 500 & 570 & 375 & 463 & 205 \\
\hline Solunsisällysaineet ${ }^{1)}$ & 414 & 355 & 523 & 444 & 741 \\
\hline Sokeri & 61,3 & 30,7 & 16,5 & 19,9 & \\
\hline Maitohappo & 61,7 & 55,9 & 50,1 & 38,2 & \\
\hline Käymishapot yhteensä & 97,3 & 81,6 & 85,3 & 72,9 & \\
\hline \multicolumn{6}{|l|}{ g/kg kokonais-N } \\
\hline Ammonium-N & 44 & 44 & 25 & 32 & \\
\hline Liukoinen N & 561 & 536 & 277 & 288 & \\
\hline Orgaanisen aineen sulavuus, $\mathrm{g} / \mathrm{kg}^{2)}$ & 777 & 729 & 758 & 672 & \\
\hline D-arvo, g/kg ka²) & 714 & 673 & 678 & 610 & \\
\hline ME, MJ/kg ka & 11,4 & 10,8 & 10,8 & 9,8 & 12,2 \\
\hline OIV, g/kg ka & 86 & 81 & 93 & 84 & 106 \\
\hline PVT, g/kg ka & -12 & -26 & 53 & 37 & $-7,2$ \\
\hline Syönti-indeksi & 102 & 96 & 104 & 95 & \\
\hline
\end{tabular}

${ }^{1)}$ Solunsisällysaineet $=$ Orgaaninen aine $-\mathrm{NDF} ;{ }^{2)}$ määritetty in vivo pässeillä 
Pötsin ammoniakkipitoisuus oli heinäkasviruokinnoilla paljon pienempi $(\mathrm{P}<0.001)$ kuin apilaruokinnoilla (taulukko 2) heijastaen vastaavaa eroa säilörehujen raakavalkuaispitoisuuksissa. Aikaisemmassa kokeessa pötsin ammoniakkipitoisuuksissa ei ollut eroja kun apila- ja heinäkasviruokintojen raakavalkuaispitoisuus oli sama (Vanhatalo ym. 1995). Pötsin haihtuvien rasvahappojen (VFA) pitoisuus oli apilaruokinnoilla suurempi $(\mathrm{P}<0.001)$ kuin heinäkasviruokinnoilla samoin kuin aikaisemmissa kokeissa (Vanhatalo ym. 1995, Dewhurst ym. 2003, Bertilsson ja Murphy 2003). Heinäkasviruokintoihin verrattuna apilaruokintojen etikkahapon osuus pötsikäymisen lopputuotteista lisääntyi selvästi propioni- ja voihapon osuuksien kustannuksella. Muissa kokeissa pötsikäymisen lopputuotteiden mooliosuuksissa ei ole ollut näin suuria kasvilajien välisiä eroja riippumatta siitä onko apila annettu yksinomaisena rehuna tai seoksena (Vanhatalo ym. 1995, Dewhurst ym. 2003, Bertilsson ja Murphy 2003). Heinäkasvisäilörehut sisälsivät tässä kokeessa hieman enemmän maitohappoa ja sokeria kuin apilarehut, mutta kasvilajien väliset erot säilönnällisessä laadussa olivat aika pieniä selittääkseen todettua eroa pötsikäymisessä. Syy eroihin pötsikäymisessä saattaa liittyä kasvilajien erilaiseen solunseinäaineiden koostumukseen (Kuoppala ym. 2005). Kasvuasteen edetessä muutokset vertailtavien ruokintojen pötsikäymisessä olivat melko pieniä ja samansuuntaisia kasvilajista riippumatta.

Samoin kuin aikaisemmissa kokeissa (Vanhatalo ym. 1995, Dewhurst ym. 2003) pötsistä virtasi enemmän NAN:ä, ja mikrobisynteesi oli tehokkaampaa apila- kuin heinäkasviruokinnoilla (taulukko 3). Apilaruokintojen runsaampi NAN-virtaus johtui suuremmasta ei-mikrobitypen virtauksesta pikemminkin kuin suuremmasta mikrobitypen virtauksesta. Apilaruokintojen rehuperäisen valkuaisen pötsihajovuus in vivo oli näin ollen myös tässä kokeessa heinäkasviruokintoja pienempi (Vanhatalo ym. 1995, Dewhurst ym. 2003). Syynä tähän on ilmeisesti puna-apilan sisältämän polyfenolioksidaasin proteolyysiä ehkäisevä vaikutus (Jones 1995).

Apilaruokinnoilla pötsistä satakertaan virtasi aminotyppeä merkitsevästi enemmän $(\mathrm{P}<0.01)$ kuin heinäkasviruokinnoilla (taulukko 4). Tämä johtui apilaruokintojen sekä välttämättömien että eivälttämättömien aminohappojen suuresta virtauksesta. Metioniinia lukuun ottamatta kaikkien yksittäisten välttämättömien aminohappojen, kuten histidiinin, virtaus oli suurempi apilaruokinnoilla. Heinäkasviruokinnoilla histidiiniä virtasi pötsistä määrällisesti selvästi vähemmän kuin metioniinia kuten myös aikaisemmissa kokeissa (Korhonen ym. 2002b, Korhonen ym. julkaisematon); sen sijaan apilaruokinnoilla histidiiniä ja metioniinia virtasi pötsistä yhtä paljon (histidiini/metioniini 0,85, 0,84, 0,97, 0,98, 0,94 ruokinnoilla Ha, Hm, Aa, Am, HmAa, vastaavasti). Korhosen ym. (2002a) kokeessa, jossa perusrehuna oli apilaa sisältävä säilörehu, histidiiniä virtasi jopa enemmän kuin metioniinia. Kirjallisuudessa ei ole julkaistu yksittäisten aminohappojen virtauksia palkokasviruokinnoilla. Kotimaisten kokeiden perusteella näyttää siltä, että puna-apilan sisällyttäminen ruokintaan lisää lehmien aminohappojen, mm. histidiinin saantia. Histidiini on todettu tuotantoa eniten rajoittavaksi aminohapoksi viljaan ja heinäkasvisäilörehuun perustuvalla ruokinnalla (Vanhatalo ym. 1999). Kasvuasteen vaikutus aminohappojen virtaukseen ei ollut tilastollisesti merkitsevä. Kasvuasteen edetessä aminohappojen virtaus kuitenkin pieneni numeerisesti heinäkasviruokinnoilla, mutta ei muuttunut apilaruokinnoilla. Tämä saattoi heijastaa mikrobitypen virtauksessa todettua eroa: kun mikrobitypen tuotanto heinäkasviruokinnoilla pieneni kasvuasteen edetessä, se apilaruokinnalla lisääntyi $(\mathrm{P}<0.05)$.

Runsaampi aminohappojen virtaus ohutsuoleen näkyi apilaruokinnoilla heinäkasviruokintoihin verrattuna suurempina haaraketjuisten ja välttämättömien aminohappojen pitoisuuksina plasmassa (taulukko 5). Tällöin kuitenkin myös apilaruokintojen plasman ureapitoisuudet nousivat $(\mathrm{P}<0.001)$ merkittävästi (7,0 vs. 2,9 mmol/l). Kokeessa käytetty väkirehu sisälsi rypsiä, mistä johtuen plasman histidiinipitoisuus oli suhteellisen korkea kaikilla koeruokinnoilla. Tässä kokeessa histidiini ei luultavasti ollut tuotantoa rajoittava aminohappo. Plasman pienistä metioniinipitoisuuksista päätelleen tuotantoa rajoittavaksi aminohapoksi saattoi muodostua metioniini. Tähän viittaa myös se, että maitorauhasen aminohappojen ekstraktioista metioniinin ekstraktiot olivat suurimpia sekä heinäkasviettä apilaruokinnoilla (tuloksia ei esitetty). Leusiinin ekstraktiot olivat merkitsevästi $(\mathrm{P}<0.05)$ suurempia heinäkasvi- kuin apilaruokinnoilla viitaten siihen, että myös leusiinin saannista saattoi olla puutetta heinäkasviruokinnoilla.

Maitotuotoksissa ei ollut kasvilajista tai säilörehujen kasvuasteesta johtuvia tilastollisesti merkitseviä eroja (taulukko 6). Vähäisemmästä säilörehun syönnistä huolimatta apilaa syöneiden lehmien EKM- ja maitotuotokset olivat yhtä suuria kuin heinäkasvirehuja syöneiden lehmien 
tuotokset. Myöskään valkuais- tai rasvatuotoksissa ei ollut eroja. Toisaalta vaikka lehmät söivät apilan ja heinäkasvin seosta selvästi enemmän kuin kumpaakaan rehua yksinään maitotuotos ei silti lisääntynyt.

Maidon rasva- ja valkuaispitoisuudet olivat merkitsevästi $(\mathrm{P} \leq 0.01)$ pienempiä, ja maidon ureapitoisuudet suurempia $(\mathrm{P}<0.001)$ apila- kuin heinäkasviruokinnoilla. Rasvapitoisuuden pieneneminen oli yhteydessä apilaruokintojen pienempään voihapon osuuteen pötsin VFA:sta. Heinäkasvirehujen pienistä raakavalkuaispitoisuuksista johtuen rehuvalkuaisen hyväksikäyttö (maidon $\mathrm{N} /$ ruokinnan $\mathrm{N})$ oli merkitsevästi $(\mathrm{P}<0.001)$ suurempi heinäkasvi- kuin apilaruokinnoilla. Tuotosvasteet olivat samansuuntaisia kuin Tuorin ym. (2002) kokeessa, jossa heinäkasvisäilörehua korvattiin puhtaalla puna-apilalla. Hyvää maitotuotosta apilaruokinnoilla tässä kokeessa selitti osaltaan myös se, että plasman vapaiden rasvahappojen pitoisuudet olivat jonkin verran suuremmat $(\mathrm{P}<0.05)$ apila- kuin heinäkasviruokinnoilla (0,144 vs. 0,106 mmol/l) viitaten runsaampaan kudosvarastojen käyttöön apilaruokinnoilla.

Taulukko 2. Rehujen syönti ja ravintoaineiden saanti sekä pötsifermentaatio

\begin{tabular}{|c|c|c|c|c|c|c|c|c|c|c|}
\hline & На & Hm & Aa & Am & HmAa & SEM & $\begin{array}{c}\text { H vs. } \\
\text { A }\end{array}$ & $\begin{array}{c}\text { a vs. } \\
\text { m }\end{array}$ & yhd. & $\begin{array}{l}\text { Hm, Aa } \\
\text { vs. seos }\end{array}$ \\
\hline \multicolumn{11}{|c|}{ Rehujen syönti ja ravintoaineiden saanti, kg/pv } \\
\hline Säilörehun ka & 13,2 & 12,0 & 11,3 & 12,1 & 14,0 & 0,49 & 0 & & o & ** \\
\hline Rehujen ka yhteensä & 21,2 & 20,1 & 18,8 & 20,2 & 21,5 & 0,59 & o & & o & $*$ \\
\hline Orgaaninen aine & 19,3 & 18,4 & 17,2 & 18,5 & 19,8 & 0,54 & 0 & & 0 & $*$ \\
\hline Raakavalkuainen & 3,05 & 2,62 & 3,63 & 3,52 & 3,49 & 0,089 & $* * *$ & * & & * \\
\hline NDF & 8,16 & 8,41 & 6,56 & 7,23 & 8,35 & 0,537 & $*$ & & & \\
\hline \multicolumn{11}{|c|}{ Pötsifermentaatio, mmol/l tai mmol/mol } \\
\hline $\mathrm{pH}$ & 6,40 & 6,45 & 6,25 & 6,51 & 6,32 & 0,074 & & 0 & & \\
\hline $\mathrm{NH}_{3}$ & 3,92 & 2,82 & 7,52 & 7,45 & 5,31 & 0,455 & $* * *$ & & & \\
\hline Kokonais-VFA & 108 & 102 & 120 & 115 & 117 & 2,5 & $* * *$ & $*$ & & 0 \\
\hline Etikkahappo & 634 & 647 & 687 & 687 & 669 & 3,6 & $* * *$ & $* *$ & & \\
\hline Propionihappo & 180 & 182 & 159 & 161 & 167 & 3,7 & $* * *$ & & & \\
\hline Voihappo & 144 & 134 & 126 & 116 & 127 & 3,0 & $* * *$ & $* *$ & & \\
\hline \multicolumn{11}{|l|}{ Pötsisulavuus, g/g } \\
\hline Orgaaninen aine & 0,609 & 0,591 & 0,612 & 0,563 & 0,590 & 0,0151 & & $*$ & & \\
\hline NDF & 0,578 & 0,545 & 0,567 & 0,484 & 0,570 & 0,0268 & & & o & \\
\hline \multicolumn{11}{|l|}{ Kokonaisulavuus, g/g } \\
\hline Orgaaninen aine & 0,750 & 0,719 & 0,762 & 0,723 & 0,738 & 0,0605 & & $* * *$ & & \\
\hline NDF & 0,621 & 0,580 & 0,632 & 0,547 & 0,616 & 0,0239 & & $*$ & & \\
\hline Pötsisul./kok.sulatus & 0,930 & 0,940 & 0,895 & 0,884 & 0,924 & 0,0146 & $*$ & & & \\
\hline
\end{tabular}

Ruokinnalta HmAa puuttuu yksi havainto, ja sen SEM saadaan kertomalla SEM luvulla 1.19.

Taulukko 3. Typen saanti, virtaus satakertaan, sulavuus, sekä mikrobisynteesin tehokkuus

\begin{tabular}{|c|c|c|c|c|c|c|c|c|c|c|}
\hline & На & Hm & Aa & Am & HmAa & SEM & $\begin{array}{c}\text { H vs. } \\
\text { A }\end{array}$ & $\begin{array}{c}\text { a vs. } \\
\text { m }\end{array}$ & yhd. & $\begin{array}{l}\text { Hm, Aa } \\
\text { vs. seos }\end{array}$ \\
\hline Typen saanti, g/pv & 488 & 419 & 581 & 563 & 559 & 14,2 & $* * *$ & $*$ & & $*$ \\
\hline \multicolumn{11}{|c|}{ Typen virtaus satakertaan, g/pv } \\
\hline NAN & 476 & 409 & 531 & 532 & 555 & 28,3 & $* *$ & & & 0 \\
\hline Mikrobi-N (MN) & 335 & 282 & 318 & 345 & 358 & 18,1 & & & $*$ & $*$ \\
\hline Ei-mikrobi-N & 145 & 130 & 219 & 191 & 202 & 12,0 & $* * *$ & & & \\
\hline \multicolumn{11}{|l|}{ Typen eritys, g/pv } \\
\hline Sonta & 156 & 139 & 156 & 167 & 174 & 6,1 & $*$ & & $*$ & ** \\
\hline \multicolumn{11}{|l|}{ Typen sulavuus , g/g } \\
\hline Pötsi, näennäinen & 0,014 & 0,017 & 0,093 & 0,044 & 0,006 & 0,0411 & & & & \\
\hline Pötsi, todellinen & 0,705 & 0,688 & 0,627 & 0,658 & 0,641 & 0,0190 & * & & & \\
\hline Koko rs-kanava\# & 0,681 & 0,668 & 0,732 & 0,703 & 0,689 & 0,0058 & $* * *$ & $* *$ & & \\
\hline \multicolumn{11}{|c|}{ Mikrobisynteesin tehokkuus } \\
\hline g MN/kg OMTDR & 21,8 & 20,4 & 22,9 & 24,2 & 23,1 & 0,99 & $*$ & & & \\
\hline
\end{tabular}

Ruokinnalta HmAa puuttuu yksi havainto, ja sen SEM saadaan kertomalla SEM luvulla 1.19.

NAN=ei-ammoniakkityppi; OMTDR= pötsissä todellisesti sulanut orgaaninen aine: \# näennäinen sulavuus 
Taulukko 4. Aminohappojen virtaus satakertaan, g/pv

\begin{tabular}{|c|c|c|c|c|c|c|c|c|c|c|}
\hline & На & Hm & Aa & Am & HmAa & SEM & $\begin{array}{c}\text { H vs. } \\
\text { A }\end{array}$ & $\begin{array}{c}\text { a vs. } \\
\text { m }\end{array}$ & yhd. & $\begin{array}{l}\text { Hm, Aa } \\
\text { vs. seos }\end{array}$ \\
\hline Arginiini & 114 & 98 & 141 & 130 & 130 & 8,0 & $* *$ & & & \\
\hline Fenyylialaniini & 123 & 104 & 154 & 150 & 153 & 8,0 & $* * *$ & & & 0 \\
\hline Histidiini & 51 & 43 & 61 & 59 & 61 & 3,2 & $* *$ & & & 0 \\
\hline Isoleusiini & 118 & 98 & 139 & 138 & 142 & 7,4 & $* *$ & & & $*$ \\
\hline Leusiini & 189 & 158 & 233 & 224 & 227 & 11,9 & $* * *$ & & & o \\
\hline Lysiini & 143 & 123 & 167 & 165 & 164 & 10,0 & $* *$ & & & \\
\hline Metioniini & 60 & 51 & 64 & 60 & 65 & 3,9 & & & & \\
\hline Treoniini & 119 & 103 & 145 & 137 & 140 & 8,3 & $* *$ & & & \\
\hline Valiini & 119 & 96 & 135 & 138 & 144 & 6,5 & $* * *$ & & o & $* *$ \\
\hline Haaraketjuiset AH & 427 & 352 & 507 & 500 & 512 & 25,3 & $* * *$ & & & $*$ \\
\hline Välttämättömät AH & 1037 & 875 & 1240 & 1201 & 1225 & 65,3 & $* *$ & & & 0 \\
\hline Ei-välttämättömät AH & 1243 & 1049 & 1448 & 1407 & 1430 & 76,9 & $* *$ & & & \\
\hline AH, yhteensä & 2286 & 1930 & 2693 & 2615 & 2662 & 142,0 & $* *$ & & & 0 \\
\hline AH, g/g kok.RV & 0,762 & 0,749 & 0,802 & 0,781 & 0,761 & 0,0122 & $* *$ & & & \\
\hline
\end{tabular}

Ruokinnalta HmAa puuttuu yksi havainto, ja sen SEM saadaan kertomalla SEM luvulla 1.19.

$\mathrm{AH}=$ aminohapot; $\mathrm{RV}=$ raakavalkuainen;

Taulukko 5. Plasman aminohapot, $\mu \mathrm{mol} / \mathrm{l}$

\begin{tabular}{|c|c|c|c|c|c|c|c|c|c|}
\hline & На & Hm & Aa & Am & HmAa & SEM & $\begin{array}{c}\text { H vs. } \\
\text { A }\end{array}$ & $\begin{array}{l}\text { a vs. yhd. } \\
\text { m }\end{array}$ & $\begin{array}{c}\text { Hm, Aa } \\
\text { vs. seos }\end{array}$ \\
\hline Arginiini & 71 & 64 & 88 & 88 & 79 & 9,2 & 0 & & \\
\hline Fenyylialaniini & 37 & 41 & 59 & 54 & 47 & 3,3 & $* * *$ & & \\
\hline Histidiini & 42 & 46 & 54 & 47 & 52 & 4,6 & & & \\
\hline Isoleusiini & 109 & 115 & 193 & 159 & 144 & 16,6 & $* *$ & & \\
\hline Leusiini & 104 & 99 & 228 & 181 & 169 & 14,1 & $* * *$ & & \\
\hline Lysiini & 74 & 76 & 111 & 92 & 91 & 7,0 & $* *$ & & \\
\hline Metioniini & 17 & 18 & 18 & 15 & 18 & 1,1 & & & \\
\hline Treoniini & 98 & 100 & 119 & 126 & 125 & 8,1 & * & & \\
\hline Tryptofaani & 28 & 18 & 27 & 21 & 27 & 7,3 & & & \\
\hline Valiini & 204 & 216 & 374 & 287 & 270 & 26,9 & * & & \\
\hline Haaraketjuiset AH & 417 & 430 & 795 & 626 & 582 & 52,9 & $* * *$ & & \\
\hline Välttämättömät AH & 783 & 793 & 1270 & 1068 & 1021 & 71,9 & $* * *$ & & \\
\hline Ei-välttämättömät AH & 1083 & 1019 & 1087 & 1069 & 1131 & 57,4 & & & \\
\hline AH, yhteensä & 1866 & 1811 & 2357 & 2137 & 2151 & 120,5 & $* *$ & & \\
\hline
\end{tabular}

Ruokinnalta HmAa puuttuu yksi havainto, ja sen SEM saadaan kertomalla SEM luvulla 1.19; AH=aminohapot.

Taulukko 6. Maitotuotos ja maidon koostumus

\begin{tabular}{|c|c|c|c|c|c|c|c|c|c|c|}
\hline & На & Hm & Aa & Am & HmAa & SEM & $\begin{array}{c}\text { H vs. } \\
\text { A }\end{array}$ & $\begin{array}{c}\text { a vs. } \\
\text { m }\end{array}$ & yhd. & $\begin{array}{c}\text { Hm, Aa } \\
\text { vs. seos }\end{array}$ \\
\hline \multicolumn{11}{|l|}{ Tuotos, kg/pv } \\
\hline Maito & 27,1 & 25,6 & 27,7 & 27,4 & 27,8 & 0,94 & & & & \\
\hline EKM\# & 26,8 & 25,4 & 25,5 & 26,2 & 26,6 & 0,79 & & & & \\
\hline Rasva & 1093 & 1034 & 997 & 1054 & 1058 & 30,5 & & & 0 & \\
\hline Valkuainen & 874 & 824 & 815 & 828 & 865 & 29,0 & & & & \\
\hline Laktoosi & 1248 & 1191 & 1307 & 1284 & 1307 & 47,4 & & & & \\
\hline \multicolumn{11}{|c|}{ Maidon koostumus, g/kg } \\
\hline Rasva & 40,9 & 41,2 & 37,4 & 39,4 & 38,6 & 0,76 & $* *$ & & & \\
\hline Valkuainen & 32,6 & 32,6 & 30,4 & 30,8 & 31,5 & 0,38 & $* * *$ & & & \\
\hline Laktoosi & 46,1 & 46,6 & 47,0 & 46,7 & 46,9 & 0,21 & $*$ & & & \\
\hline Urea, mg/100 ml & 14,3 & 14,0 & 36,9 & 35,7 & 24,9 & 1,12 & $* * *$ & & & \\
\hline Valk.tuot/RV-saanti & 0,285 & 0,315 & 0,223 & 0,237 & 0,248 & 0,0077 & $* * *$ & $*$ & & o \\
\hline EKM/kg ka & 1,26 & 1,27 & 1,34 & 1,30 & 1,24 & 0,026 & $*$ & & & o \\
\hline EKM/MJ ME & 0,11 & 0,11 & 0,12 & 0,12 & 0,11 & 0,002 & $* *$ & & & \\
\hline
\end{tabular}

\#Energiakorjattu maitotuotos 


\section{Johtopäätökset}

Kokeen tulokset viittaavat siihen, että nurmen kasvuasteen vaikutus säilörehun syöntiin ja ravintoaineiden saantiin apilalla ja heinäkasveilla ei ole samanlainen. Apilan kasvuasteen vaikutuksista lehmien tuotosvasteisiin tarvitaan lisätutkimuksia.

Puna-apilan käyttö ruokinnassa lisää lypsylehmien aminohappojen saantia heinäkasvirehuihin verrattuna. Puhdasta puna-apilaa käytettäessä rehuannoksen raakavalkuaispitoisuus voi kuitenkin nousta tarpeettoman suureksi, jolloin rehuvalkuaisen hyväksikäyttö väistämättä huononee.

\section{Kirjallisuus}

Ahvenjärvi, S., Vanhatalo, A., Huhtanen, P. and Varvikko, T. 2000. Determination of reticulo-rumen and whole-stomach digestion in lactating cows by omasal canal or duodenal sampling. Br. J. Nutr. 83:67-77.

Bertilsson, J. \& Murphy, M. 2003. Effects of feeding clover silages on feed intake, milk production and digestion in dairy cows. Grass and Forage Science 58:309-322.

Dewhurst, R. J., Evans, R. T., Scollan, N. D., Moorby, J. M., Merry, R. J. and Wilkins R. J. 2003. Comparison of Grass and Legume Silages for Milk Production. 2. In Vivo and In Sacco Evaluations of Rumen Function. J. Dairy Sci. 86: 2612-2621.

Heikkilä, T., Toivonen, V., Mela, T. 1992. Comparison of red clover-grass silage with grass silage for milk production. In: Proceedings of the 14th General Meeting of the European Grassland Federation, Lahti, Finland, June 8-11, 1992. p. 388-391.

Jones, B. A.1995. Red clover extracts inhibit legume proteolysis. Journal of Science of Food and Agriculture 67:329-333.

Korhonen, M., Ahvenjärvi, S., Vanhatalo, A., Huhtanen, P. 2002a. Supplementing barley or rapeseed meal to dairy cows fed grass-red clover silage. 2. Amino acid profile of microbial fractions. Journal of Animal Science 80:2188-2196.

Korhonen, M., Vanhatalo, A., Huhtanen, P. 2002b. Effect of protein source on amino acid supply, milk production, and metabolism of plasma nutrients in dairy cows fed grass silage. Journal of Dairy Science 85:3336-3351.

Kuoppala, K., Ahvenjärvi, S., Rinne, M., Vanhatalo, A. 2006. Puna-apilasäilörehun solunseinäkuitu on erilaista kuin timotei-nurminatasäilörehun. Maataloustieteen päivät 2006.

Rinne, M. 2000. Influence of the timing of the harvest of primary grass growth on herbage quality and subsequent digestion and performance in the ruminant animal. Helsingin yliopiston kotieläintieteen laitoksen julkaisuja 54: 42 p. +5 encl. Diss.: Helsinki: Helsingin yliopisto, 2000. (Väitöskirja). http://ethesis.helsinki.fi/ julkaisut/maa/kotie/vk/rinne/.

Thomas, C., Aston, K. \& Daley, S.R. 1985. Milk production from silage 3. A comparison of red clover with grass silage. Animal Production 41:23-31.

Tuori, M. ja Syrjälä-Qvist, L. 2001. Nurmipalkokasvisäilörehut lypsylehmien ruokinnassa. Nurmipalkokasvien tuotanto ja käyttömahdollisuudet. Professori Liisa Syrjälä_Qvistin juhlaseminaari 1.11.2001. p. 38-47.

Tuori, M., Syrjälä-Qvist, L. \& Jansson, S. 2002. Puna-apila- ja nurminatasäilörehu eri suhteissa lypsylehmien ruokinnassa. In: Rinne, M. (toim.). Maataloustieteen Päivät 2002. Kotieläintiede. Maaseutukeskusten Liiton julkaisuja nro 977. p. 143-146.

Vanhatalo, A., Heikkilä, T., Gäddnäs, T. 1995. Puna-apilapitoinen säilörehu lypsylehmien ruokinnassa: vaikutus valkuaissynteesiin, pötsifermentaatioon ja maidontuotantoon heinäsäilörehuun verrattuna. In: Jokela, M. (toim.). Kotieläintieteen Päivät 1995. Maaseutukeskusten Liiton julkaisuja nro 888. p. 190-193.

Vanhatalo, A., Huhtanen, P., Toivonen, V. \& Varvikko, T. 1999. Response of dairy cows fed grass silage diets to abomasal infusions of histidine alone or in combinations with methionine and lysine. Journal of Dairy Science 82: 2674-2685. 